\title{
UJI ORGANOLEPTIK PRODUK OLAHAN BAKSO KOMBINASI JANTUNG PISANG, KACANG MERAH (PHASEOLUS VULGARIS) DAN \\ UBI JALAR (IPOMEA BATATAS L)
}

\author{
Tutik Alawiyah ${ }^{1}$, Intje Picauly ${ }^{2}$, Grouse T.S. Oematan ${ }^{3}$, Marthen R Pellokila ${ }^{4}$ \\ ${ }^{1}$ Politeknik Kesehatan Kemenkes RI_Kupang \\ ${ }^{2-3}$ Program Studi Ilmu Kesehatan Masyarakat, FKM Undana \\ ${ }^{4}$ Fakultas Pertanian, Undana
}

\author{
Dinyatakan Layak Publikasi : \\ Kupang, 12 Maret 2019
}

\begin{abstract}
$\mathcal{A B S T R \mathcal { A K }}$
Bakso merupakan makanan yang digemari dan mempunyai daya terima yang tinggi di semua kalangan mulai dari balita sampai dewasa. Bakso yang sudah banyak diproduksi dan dijual bebas di pasar memiliki banyak alternatif kombinasi diantaranya tepung dan daging (sapi, ayam, dan ikan). Sumber pangan lokal di wilayah NTT dapat dijadikan sebgai alternatif dalam membuat bakso berbahan jantung pisang, kacang merah, dan ubi jalar. Bakso dapat dibuat dengan mengkombinasikan ketiga jenis pangan lokal (jantung pisang, kacang merah dan ubi jalar) sehingga dapat menjadi alternatif makanan tambahan bergizi dan bebas BTP yang dapat diterima oleh semua kalangan dari balita sampai orang dewasa. Jenis penelitian ini merupakan rancangan penelitian eksperimen di bidang teknologi pangan. Rancangan penelitian adalah rancangan acak lengkap (RAL). Data uji organoleptic (daya terima dan masa simpan) diolah secara statistic menggunakan Analisis of Varians (ANOVA) dengan menggunakan software SPSS17. Apabila di antara perlakuan terdapat pengaruh maka dilanjutkan dengan uji Tukey Honestly Significance Difference (HSD). Rata-rata uji daya terima bakso jantung pisang diperoleh hasil rata-rata kesukaan (warna, aroma, tekstur dan rasa) berkisar 3.35 sampai 3.97 yang berarti masuk dalam kategori suka. Dari hasil rata-rata diketahui bahwa perlakuan P32 adalah perlakuan yang paling tinggi nilainya yaitu 3,97 yang artinya P32 adalah produk pentolan bakso jantung pisang yang paling disukai oleh panelis.
\end{abstract}

Kata kunci : Bakso Jantung Pisang, Alternatif, Makanan Tambahan, Daya Terima
Key words: Banana Heart, Meatball, Alternative, Supplementary Food 


\section{PENDAHULUAN}

Bakso merupakan makanan yang digemari dan mempunyai daya terima yang tinggi oleh semua kalangan mulai dari balita sampai dewasa. Menurut observasi awal yang dilakukan ditemukan bahwa pentolan bakso yang sudah banyak diproduksi dan dijual bebas dipasar memiliki banyak alternatif kombinasi, diantaranya tepung dan daging (sapi, ayam dan ikan), namun belakangan ini sudah banyak juga beredar dipasaran pentolan bakso tanpa kombinasi atau berbahan baku tepung semata dengan menggunakan BTP (bahan tambahan pangan) sebagai bumbu penyedap. Secara kimiawi diketahui bahwa penggunaan BTP yang berlebihan akan berakibat buruk pada kesehatan.

Sumber pangan lokal diwilayah Propinsi NTT dapat dijadikan sebagai alternatif dalam membuat bakso yaitu jantung pisang, kacang merah dan ubi jalar. Data BPS Propinsi NTT (2015) menerangkan bahwa produksi ketiga bahan pangan ini cukup berlimpah, dimana hasil produksi jantung pisang diwakili produksi pisang yaitu sebesar $1.298 .782 \mathrm{kw}$, kacang merah 3,978 ton dan ubi jalar 59.608 ton pada tahun 2014. Namun sampai saat ini pengolahan ketiga bahan pangan tersebut masih berskala olahan rumah tangga atau olahan tradisional seperti rebus, goreng, kripik, cake dan lain-lain.

Berdasarkan kenyataan yang ada maka peneliti dapat berasumsi bahwa membuat pentolan bakso dengan mengkombinasikan ketiga jenis pangan lokal (jantung pisang, kacang merah dan ubi jalar) dapat menjadi alternatif makanan tambahan bergizi dan bebas BTP yang dapat diterima oleh semua kalangan dari balita sampai orang dewasa dan diharapkan dapat mendukung upaya peningkatkan keanekaragaman pangan fungsional di NTT.

\section{METODE PENELITIAN}

Jenis penelitian ini merupakan penelitian eksperimen di bidang teknologi pangan. Rancangan penelitian yang digunakan adalah Rancangan Acak Lengkap (RAL) yaitu P0, P1, P2, dan P3 dimana P0 adalah resep standar pengolahan pentolan bakso jantung pisang tanpa kombinasi tepung kacang merah dan tepung ubi jalar. Sedangkan 3 (tiga) perlakuan lainnya dengan perbandingan proporsi jantung pisang : tepung kacang merah : tepung ubi jalar, dimana P1 (45:25: 30), P2 (50: 15 
: 35), P3 (55: $5: 40$ ) dengan 3 (tiga) kali pengulangan sehingga menghasilkan sebanyak 30 unit penelitian. Unit penelitian tersebut diuji nilai daya terima (mutu organoleptik).

\section{HASIL DAN PEMBAHASAN}

Pentolan bakso dibuat dengan kombinasi pangan lokal ( jantung pisang, tepung kacang merah, tepung ubi jalar) dengan proporsi bahan : P0 (resep standar bakso) , P1 (45:25:30) , P2 (50:15:35) , P3 (55:5:40), berikut masing-masing taraf perlakuan (Tabel 1) dalam pembuatan pentolan bakso jantung pisang dapat dilihat dalam tabel dibawah ini.

Tabel 1. Taraf Perlakuan Pembuatan Pentolan Bakso Jantung Pisang

\begin{tabular}{llcccc}
\hline Pro & & Jantung Pisang & $\begin{array}{l}\text { Kacang } \\
\text { Merah }\end{array}$ & Ubi Jalar & Tapioka \\
\hline P0 & $:$ & $50 \%$ & - & - & $50 \%$ \\
P11 & $:$ & $45 \%$ & $25 \%$ & $30 \%$ & $5 \%$ \\
P12 & $:$ & $25 \%$ & $45 \%$ & $30 \%$ & $5 \%$ \\
P13 & $:$ & $30 \%$ & $25 \%$ & $45 \%$ & $5 \%$ \\
P21 & $:$ & $50 \%$ & $15 \%$ & $35 \%$ & $5 \%$ \\
P22 & $:$ & $15 \%$ & $50 \%$ & $35 \%$ & $5 \%$ \\
P23 & $:$ & $35 \%$ & $15 \%$ & $50 \%$ & $5 \%$ \\
P31 & $:$ & $55 \%$ & $5 \%$ & $40 \%$ & $5 \%$ \\
P32 & $:$ & $5 \%$ & $55 \%$ & $40 \%$ & $5 \%$ \\
P33 & $:$ & $40 \%$ & $5 \%$ & $55 \%$ & $5 \%$ \\
\hline
\end{tabular}

Daya terima produk pentolan bakso jantung pisang, di uji dengan uji organoleptik pada tanggal 30 Mei 2017 Dengan panelis mahasiswa semester IV Prodi Gizi Poltekkes Kemenkes Kupang, dari hasil uji organoleptik didapatkan hasil penilaian sebagai berikut :

Tabel 2. Rata-rata Hasil Uji Daya Terima Pentolan Bakso Jantung Pisang

\begin{tabular}{cccccc}
\hline \multirow{2}{*}{ Perlakuan } & \multicolumn{5}{c}{ Aspek } \\
& Warna & Aroma & Tekstur & Rasa & Rata-rata \\
\hline P0 & 3.50 & 2.97 & 3.50 & 3.43 & 3.35 \\
P11 & 3.97 & 3.40 & 3.57 & 3.13 & 3.52 \\
P12 & 3.93 & 3.60 & 3.37 & 3.20 & 3.53 \\
P13 & 4.07 & 3.50 & 3.80 & 3.60 & 3.74 \\
P21 & 3.80 & 3.67 & 3.23 & 3.77 & 3.62 \\
P22 & 3.97 & 3.33 & 3.63 & 3.47 & 3.60 \\
P23 & 3.70 & 3.50 & 3.67 & 3.60 & 3.62 \\
P31 & 3.47 & 3.47 & 3.33 & 3.50 & 3.44 \\
P32 & 4.17 & 4.07 & 3.90 & 3.73 & 3.97 \\
P33 & 3.93 & 3.60 & 3.53 & 3.57 & 3.66 \\
\hline
\end{tabular}

Keterangan : 1= sangat tidak suka, 2= tidak suka, 3= agak suka, 4=suka, 5=sangat suka 
Rata-rata uji daya terima pentolan bakso jantung pisang diperoleh hasil ratarata kesukaan (warna, aroma, tekstur dan rasa) berkisar 3.35 sampai 3.97 yang berarti masuk dalam kategori suka (Tabel 2). Dari hasil rata-rata diketahui bahwa perlakuan P32 adalah perlakuan yang paling tinggi nilainya yaitu 3,97 yang artinya P32 adalah produk pentolan bakso jantung pisang yang paling disukai oleh panelis.

Hasil uji statistik mutu organoleptik menunjukkan bahwa adanya perbedaan mutu uji organoleptik pada warna dan aroma ( $\mathrm{p}$ value $<0.05$ ), hal ini dimungkinkan karena adanya perbedaan komposisi perlakuan. Sedangkan hasil uji statistik tekstur dan rasa menunjukkan tidak adanya perbedaan yang nyata ( $\mathrm{p}$ value $>0.05$ ) hal ini ditunjukkan dengan nilai sig 0.187 dan 0.162. Hasil statistik yang menunjukkan adanya perbedaan nyata pada warna dan aroma ( $\mathrm{P}$ Value $<0.05)$, serta tidak adanya perbedaan nyata pada tekstur dan rasa ( $\mathrm{P}$ Value $>0.05$ ), dijelaskan pada nilai hedonik dari masing- masing penilaian melalui uji organoleptik:

1. Nilai hedonik warna

Nilai hedonik tertinggi terdapat pada perlakuan (P32) jantung pisang 5\%, kacang merah 55\% dan ubi jalar $40 \%$ yaitu sebesar 4.17 (suka) dan terendah pada perlakuan (P31) jantung pisang 55\%, kacang merah 5\% dan ubi jalar 40\% sebesar 3.47 (agak suka). Pengaruh interaksi antara perbandingan jantung pisang, kacang merah dan ubi jalar terhadap nilai hedonik warna pentolan bakso jantung pisang adalah semakin tinggi jumlah jantung pisang maka nilai hedonik warna semakin rendah, sedangkan semakin rendah jumlah jantung pisang maka nilai hedonik kesukaan semakin tinggi, hal ini diduga panelis lebih menyukai pentolan bakso dengan kandungan jantung pisang yang rendah dan warna yang terang. Hal ini sesuai dengan penelitian Wattimena, 2013 tentang pembuatan bakso berbahan dasar daging ayam dan jantung pisang dimana semakin banyak pencampuran jantung pisang dan konsentrasi tepung sagu yang tinggi dapat mengahasilkan bakso dengan warna semakin gelap.

Jantung pisang mengandung senyawa fenolik akibat reaksi enzimatis yang memberi dampak warna coklat. Disamping itu, menurut Simonds (1962, dalam Pazmino-Duran et al., 2001), variasi warna pada jantung pisang berhubungan dengan keberadaan antosianin. Uji tukey dilakukan untuk mengetahui kelompok yang memiliki perbedaan nyata dengan kelompok pembanding (P0) sebagaimana dalam menunjukkan bahwa warna pada pentolan bakso jantung pisang berbeda nyata dengan perlakuan P32.

\section{Nilai hedonik aroma}

Nilai hedonik tertinggi pada penilaian aroma terdapat pada perlakuan (P32) jantung pisang 5\%, kacang merah 55\% dan ubi jalar 40\% yaitu sebesar 4,07 (suka) dan terendah pada perlakuan (P11) jantung pisang 45\%, kacang merah $25 \%$ dan ubi jalar 30\% dengan penilaian 3.40 (agak suka). Perbandingan komposisi jantung pisang, kacang merah dan ubi jalar memberikan pengaruh sangat berbeda nyata ( $\mathrm{p}$ value <0.01) . Peningkatan jumlah ubi jalar sehingga mengakibatkan penurunan 
jumlah komposisi kacang merah dan ubi jalar diduga sangat mempengaruhi aroma pentolan bakso jatung pisang yang dihasilkan. Uji tukey dilakukan untuk mengetahui kelompok yang memiliki perbedaan nyata dengan kelompok pembanding (P0) sebagaimana dalam menunjukkan bahwa aroma pada pentolan bakso jantung pisang berbeda nyata dengan perlakuan P21 dan P32.

\section{Nilai hedonik tekstur}

Perbandingan jantung pisang, kacang merah, ubi jalar dalam pembuatan pentolan bakso jantung pisang memberikan pengaruh berbeda tidak nyata ( $p$ value $>0.05$ ) terhadap nilai hedonik yang dihasilkan . Perlakuan (P32) jantung pisang 5\%, kacang merah 55\% dan ubi jalar 40\% menghasilkan tekstur yang paling disukai yaitu dengan nnilai 3.90 (agak suka-suka) oleh panelis dikarenakan pada perlakuan P32 perpaduan tepung kacang merah dan tepung ubi jalar hampir sama (55\% dan 40\%) sehingga terbentuk emulsi yang stabil, perlakuan P32 menghasilkan tekstur pentolan bakso yang kokoh dan padat (Gambar 4.1), hal ini dikarenakan karakteristik dari tepung kacang merah yang digunakan dalam penelitian ini adalah tepung kacang merah dengan perlakuan pendahuluan yaitu perendaman, perebusan dan pengupasan kulit, hal ini sesuai dengan penelitian Pangastuti, 2013 yang mengatakan bahwa pengupasan kacang merah dapat meningkatkan kecerahan, derajat putih, dan waktu basah, sekaligus menurunkan densitas Kamba dan padat pada tepung kacang merah dengan berbagai perlakuan pendahuluan.

Kombinasi perlakuan menghasilkan nilai kelarutan tepung kacang merah yang relatif rendah dibandingkan dengan tepung-tepungan lain. Komposisi kacang merah 55\% juga diduga menghasilkan sifat gelatinisasi dan kandungan protein yang cukup tinggi sehingga menghasilkan bakso yang kenyal, Indarmono, 1987 dalam Wattimena, dkk., 2013 menyatakan bahwa gelatinisasi pada bakso terdiri dari gelatinisasi pati dan gelatinisasi protein.

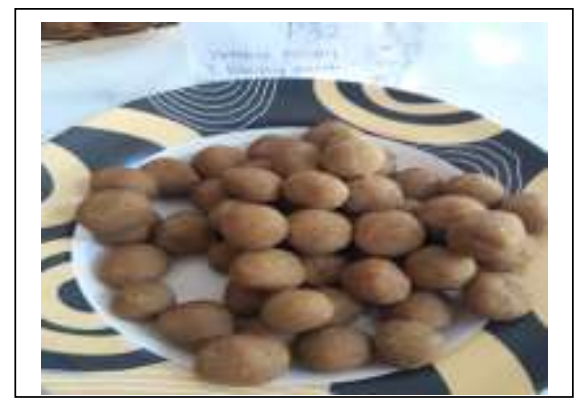

Gambar 1. Pentolan Bakso Jantung Pisang Perlakuan P32

Penilaian hedonik terendah pada perlakuan (P21) dengan komposisi jantung pisang 50\%, kacang merah 15\% dan ubi jalar 35\% yaitu 3.23 Apabila dilihat dari komposisi bahan, pentolan bakso (P21) tinggi akan jantung pisang, rendah kacang merah dan jumlah ubi jalar lebih banyak dari pada kacang merah. Dilihat dari persyaratan bakso menurut SNI, tekstur bakso seharusnya kenyal, akan tetapi pada perlakuan (P21) tekstur yang dihasilkan tidak padat (tidak dapat di bentuk), hal ini 
dimungkinkan karakter tepung ubi jalar yang mudah larut dalam air. Menurut penelitian Syamsir (2009) pengeringan ubi jalar tanpa diawali proses pengukusan, dengan penjemuran/oven akan menghasilkan tepung dengan karakteristik pati mentah.

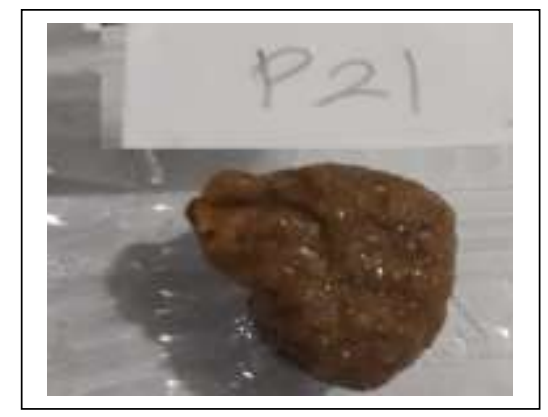

Gambar 2. Pentolan Bakso Jantung Pisang Perlakuan (P21)

\section{Nilai hedonik rasa}

Kisaran nilai 3.35 sampai 3.97 dengan nilai hedonik rasa tertinggi pada perlakuan (P21) jantung pisang 50\%, kacang merah 15\% dan ubi jalar 35\% yaitu dengan nilai 3.77 dan nilai hedonic terendah pada perlakuan jantung pisang $45 \%$, kacang merah $25 \%$ dan ubi jalar $30 \%$ nilai 3.13 (P11). Pengaruh interaksi antara jantung pisang, kacang merah dan ubi jalar terhadap nilai hedonik rasa adalah semakin semakin tinggi komposisi jantung pisang dari kacang merah dan ubi jalar, dan komposisi ubi jalar lebih tinggi dari kacang merah, maka rasanya semakin disukai oleh panelis.

Rasa jantung pisang pada penelitian yaitu jantung pisang kepok memiliki rasa yang gurih dan hambar, kacang merah mempunyai rasa gurih, sedangkan cita rasa dari tepung ubi jalar kuning sendiri yaitu agak enak dan manis. Secara deskriptif sebagian besar panelis yaitu suka terhadap formula ini dimungkinkan karena perpaduan dari rasa gurih yang berasal dari jantung pisang dan kacang merah dan juga rasa manis yang berasal ubi jalar menghasilkan rasa yang seimbang dan penambahan bumbu yang dicampurkan dalam pembuatan adonan bakso sudah menyatu dengan bahan utama yang digunakan yaitu jantung pisang, kacang merah dan ubi jalar. Hal ini sejalan dengan Kartika et al (1988) dalam Wattimena, 2013 bahwa rasa bakso yang dihasilkan terutama disebabkan oleh bumbu yang digunakan selama prosessing, yaitu garam, lada dan bawang putih sehingga menimbulkan rasa yang utuh.

\section{PENUTUP}

Kombinasi jantung pisang, kacang merah dan ubi jalar antara kontrol (P0) dan perlakuan (P11-P33) mempunyai pengaruh terhadap warna dan aroma yang ditunjukkan dengan nilai $\mathrm{P}$ Value $<0.05$, dan tidak mempunyai pengaruh terhadap tekstur dan rasa yang ditunjukkan dengan nilai $\mathrm{P}$ Value $>0.05$. dari hasil uji lanjutan diketahui bahwa : 
a. Warna pada P0 berbeda nyata dengan perlakuan P32 dipengaruhi oleh proporsi jantung pisang, semakin sedikit jantung pisang pada P32 semakin disukai oleh panelis.

b. Aroma pada P0 beda nyata dengan perlakuan P21 dan P32.

c. Tekstur dan rasa pada P0 tidak berbeda nyata dengan semua perlakuan.

\section{DAFTAR PUSTAKA}

Almatsier, S. 2003. Penuntun Diit Anak. PT Gramedia Pustaka Utama. Jakarta.

(BSN) Badan Standarisasi Nasional. 1995. Syarat Mutu Bakso Daging Sapi. SNI 013818-1995. Jakarta: Badan Standarisasi Nasional.

Badan Penelitian dan Pengembangan Kesehatan Kemenkes RI. 2013. Riset Kesehatan Dasar2013.http://www.depkes.go.id/resources/download/ general/HasilRiskesdas 2013.pdf (diakses 2 Januari 2017).

Pangastuti, HA.,Affandi, DR., Ishartani, Dwi. 2012. Karakterisasi Sifat Fisik dan Kimia Tepung Kacang Merah (Phaseolus vulgaris L) dengan beberapa perlakuan pendahuluan. Jurnal Teknosains Pangan vol 2 No 1

Syamsir. E., Honestin. T. 2009. Karakteristik Fisiko-Kimia Tepung Ubi jalar (Ipomea batatas) Varietas Sukuh dengan Variasi Proses Penepungan. Jurnal Teknologi dan Industri PanganVol XX No 2

Wattimena, M., Bintoro, V.P., Mulyani, S.2013. Kualitas Bakso Berbahan Dasar Daging Ayam Dan Jantung Pisang Dengan Bahan Pengikat Tepung Sagu. Jurnal Aplikasi Teknologi Pangan Vol 2 No 1. 